\section{To be and not to be: With wisdom and grace or stupidity and disgrace after the SARS-CoV2 outbreak}

\author{
Yue Zhang ${ }^{1-3 *}$ \\ 'Department of Rheumatology and Immunology, The First Clinical college of Harbin Medical \\ University, Harbin, China \\ ${ }^{2}$ Shenzhen Futian Hospital for Rheumatic Diseases, Shenzhen, China \\ ${ }^{3}$ Pinghu Hospital of Shenzhen University, Shenzhen, China
}

The day before yesterday, it was shameful for some politicians, especially President Trump, to label SARS-CoV2 virus as discriminatory "Chinese Virus". Politicians should be more professional and graceful, and distance themselves from the independence of the academy if something remains unknown to them. Besides, there were two months for President Trump to prepare the Americans for this Virus [1]; unfortunately, could he have given more attention to his duty of anti-SARS-CoV2 action, despite spending time to defending against the impeachment of his presidency? Besides, in line with this idea, presidential candidate Hillary Clinton wrote: "The president is turning to racist rhetoric to distract from his failures to take the coronavirus seriously early on, make tests widely available and adequately prepare the country for a period of crisis. Don't fall for it. Don't let your friends and family fall for it".

Yesterday, as the director of WHO retorted, "Should we call $\mathrm{H}_{1} \mathrm{~N}_{1}$ the American flu? No, we avoid doing. Presidential candidate Elizabeth Warren also tweeted "I've said it once and I will say it again loud enough for the White House \& Fox News and everyone else to hear: coronavirus does not discriminate. Bigotry against people of Asian descent is unacceptable, un-American and harmful to our COVID19 response efforts". We can also ask whether we should rename the Spanish flu the "American Flu"? Today, the image of Trump intentionally changing the term "coronavirus" to "Chinese Virus" in his speech notes was caught by a Washington Post photographer.

We (governments, the press, publishers and journals) could have guidelines against such dangerous aggression associated with racists to create hate and crime. Besides, it is anti-science, anti-society, immoral and anti-humanity.

As Lawrence S. Bacon, President of Harvard University, wrote yesterday, "None knows what we will face in the weeks ahead. But everyone knows enough to understand that COVID19 will test our capabilities to be kind and generous

\section{More Information}

*Address for Correspondence: Yue Zhang, \#23 Youzheng street, Nangang District, The First Clinical college of Harbin Medical University, Harbin, China 15001, Tel: 8613802448056 ; Email: toronto101@163.com; adamyuhao@163.com

Submitted: 20 March 2020

Approved: 02 April 2020

Published: 03 April 2020

How to cite this article: Zhang $Y$. To be and not to be: With wisdom and grace or stupidity and disgrace after the SARS-CoV2 outbreak. J Child Adult Vaccines Immunol. 2020; 4: 005-005.

DOI: 10.29328/journal.jcavi.1001005

Copyright: (c) 2020 Zhang Y. This is an open access article distributed under the Creative Commons Attribution License, which permits unrestricted use, distribution, and reproduction in any medium, provided the original work is properly cited.

D) Check for updates

(1) OPEn Access

and to see beyond ourselves and our own interests. Our task now is to bring the best of who we are and what we do to a world that is more complex and more confused than any of us would like it to be. May we all proceed with wisdom and grace." This is the way to go.

The origin of SARS-CoV2 remains scientifically undetermined [2] and politicians should be careful to avoid misleading their people. His speech is otherwise dampening our COVID19 response efforts in disease prevention, controlling and global co-operation. Now the world must come together as one. Furthermore, if the Chinese president or anyone else starts playing rhetorical "ping-pong" by calling COVID19 the "American Virus" or something similar, this may culminate in endless diplomatic disputes. Unlike any other business, the press or all us should be cautious to remind everyone loudly and repeatedly instead that not only scientific authors but also politicians need to obey the codes of science, society, morality and humanity [3].

\section{References}

1. Cyranosk $D$. What China's coronavirus response can teach the rest of the world. Nature. 2020; 579: 479-480.

PubMed: https://www.ncbi.nlm.nih.gov/pubmed/32203360

2. Andersen KG, Rambaut A, Lipkin WI. The proximal origin of SARSCoV-2. Nat Med. 2020. https://www.nature.com/articles/s41591020-0820-9

3. Nouri A. Council of science advisers for US lawmakers - as well as presidents. Nature. 2020; 579: 497.

PubMed: https://www.ncbi.nlm.nih.gov/pubmed/32210383 